\title{
Differentiation of rat multipotent adult progenitor cells to functional hepatocyte-like cells by mimicking embryonic liver development
}

\author{
Philip Roelandt ${ }^{1-3}$, Pau Sancho-Bru ${ }^{1,3}$, Karen Pauwelyn ${ }^{1,2} \&$ Catherine Verfaillie $^{1}$
}

\begin{abstract}
${ }^{1}$ Interdepartmental Stem Cell Institute Leuven, Catholic University Leuven, Leuven, Belgium. ${ }^{2}$ Hepatology Department, University Hospitals Leuven, Leuven, Belgium. ${ }^{3}$ These authors contributed equally to this work. Correspondence should be addressed to C.V. (Catherine.verfaillie@med.kuleuven.be).
\end{abstract}

Published online 24 June 2010; doi:10.1038/nprot.2010.80

\begin{abstract}
Differentiation of stem cells to hepatocytes has industrial applications, as well as the potential to develop new therapeutic strategies for liver disease. The protocol described here, sequentially using cytokines that are known to have a role in liver embryonic development, efficiently differentiates rat multipotent adult progenitor cells (rMAPCs) to hepatocyte-like cells by directing them through defined embryonic intermediates, namely, primitive streak/mesendoderm/definitive endoderm, hepatoblast and hepatocytelike phenotype. After 20 days, the final differentiated multipotent adult progenitor cell progeny is a mixture of cells, comprising cells with the characteristics of hepatoblasts and a smaller cell fraction with the morphological and phenotypical features of mature hepatocytes, as well as other mesodermal cells and some persistent undifferentiated rMAPCs. A detailed functional characterization of the stem cell progeny is also described; this should be used to confirm that differentiated cells display the functional characteristics of mature hepatocytes, including albumin secretion, glycogen storage and several detoxifying functions such as urea production, bilirubin conjugation, glutathione $S$-transferase activity and cytochrome activity.
\end{abstract}

\section{INTRODUCTION}

Primary hepatocytes are currently used for a number of applications: drug development, drug metabolism and drug toxicity studies (absorption, distribution, metabolism, excretion and toxicity studies, also known as ADMET studies), studies of hepatitis virus infection and creation of antiviral drugs, and investigations of new therapies for liver diseases, such as development of artificial liver devices and cell transplantation. However, hepatocytes isolated from human or animal liver can only be maintained in culture for a limited time, as they rapidly lose their phenotypic and functional characteristics. Stem or progenitor-derived functional hepatocytes have been suggested as a good alternative for primary hepatocytes, and the optimization of hepatic differentiation protocols is considered to be crucial for the further expansion of hepatocyte-like cells for applications in ADMET and therapeutic indications.

\section{Multipotent adult progenitor cells (MAPCs)}

Rodent multipotent adult progenitor cells (MAPCs) were first isolated in 2002 from the adherent fraction of the bone marrow (see Box 1 for a brief summary of an updated isolation protocol ${ }^{1}$ ). Cultured rat (r)MAPCs have extensive proliferative ( $>100$ population doublings) and multilineage differentiation capacity at the clonal level ${ }^{2,3}$. rMAPC clones express levels of Oct4 between 10 and $60 \%$ of embryonic stem cells (ESCs). Phenotypically, rMAPCs are CD90 and MHC class II negative, have low levels of MHC class I and CD44 and are CD31 positive. The transcriptome analysis shows that rMAPCs express several ESC-associated transcripts (ECATs) ${ }^{4}$, including Oct4 and Rex1, as well as $n M y c$, Lin28 and Klf4, known to have a role in the generation of iPSC, but do not express other ECATs, including Nanog, Sox 2 or the ESC gene Esrrb. Moreover, rMAPCs also express genes characteristic of primitive or visceral endoderm, such as XEN cells ${ }^{5}$ or XEN-P cells ${ }^{6}$, such as Sox7, Sox17, Gata4, Gata6, Foxa2 and $H n f 1 \beta^{3}$.

Since the description of MAPC in 2002 (ref. 7), different cell types with similar extended differentiation potency have been isolated from human or rodent tissues, including unrestricted somatic stem cells (USSCs) ${ }^{8}$, human bone marrow-derived multipotent stem cells (hBMSCs) ${ }^{9}$, marrow-isolated adult multilineage-inducible (MIAMI) cells ${ }^{10}$, amniotic fluid-derived stem (AFS) cells ${ }^{11}$, human fetal liver multipotent progenitor cells (hFLMPCs) ${ }^{12}$, very small embryonic-like cells ${ }^{13}$, pre-MSCs ${ }^{14}$, human multipotent adult stem cells (MASCs) ${ }^{15}$ and others. Similar to MAPCs, many of these cell populations display extensive expansion capacity and unexpected broad differentiation ability, as they can generate differentiated progeny beyond the boundaries of the tissue from which they were isolated. Some of the cell types described above also express Oct4, Nanog and Sox2, and, similar to ESCs, can generate cell types with the characteristics of cells from all three germ layers.

Hepatic differentiation of adult stem cells

MAPCs, pre-MSCs and MASCs generated from bone marrow ${ }^{14-16}$, USSCs generated from $\mathrm{UCB}^{17}$, AFS generated from amniotic fluid ${ }^{18}$, and hFLMPCs generated from fetal liver ${ }^{12}$ have been induced to differentiate into cells with hepatocyte-like cell characteristics in vitro. Although these cell types have a number of characteristics in common, the isolation and culture procedure, phenotype and potency are different. In 2002, we demonstrated that rMAPC lines could generate hepatocyte-like cells after a simple exposure to hepatocyte growth factor (HGF) and fibroblast growth factor (FGF)4, even though the different steps by which MAPCs acquired transcripts, proteins and functional attributes of hepatocytes were not described ${ }^{16}$. As the isolation techniques used for rMAPC isolation before 2002 differ from the ones we use now (see Box 1), the phenotype of rMAPCs used in the 2002 studies differed from that of the present rMAPC lines. Most notably, Oct4 mRNA levels were $>100$-fold lower and 2002-undifferentiated rMAPCs did not express Foxa2, Gata4 or Gata6. When we applied the cytokine mixture described previously ${ }^{16,19}$ to induce differentiation of the more recently isolated Oct $4^{\text {high }}$ rMAPC lines, 


\section{BOX 1 | ISOLATION OF RAT MULTIPOTENT ADULT PROGENITOR CELLS FROM BONE MARROW}

Bone marrow aspiration from $E 18$ or 4-week-old rats:

(i) Flush tibiae and femur with $15 \mathrm{ml}$ of PBS containing 2\% FBS under sterile conditions. Pass the flushed liquid through a 23-gauge needle.

(ii) Incubate the flushed bones for 30 min with PBS containing $0.2 \%$ collagenase and $0.02 \%$ DNase at $37{ }^{\circ} \mathrm{C}$.

(iii) Filter both cell suspensions with a $40-\mu \mathrm{M}$ cell strainer and centrifuge at $600 \mathrm{~g}$ for 6 min at room temperature $\left(20^{\circ} \mathrm{C}\right)$.

(iv) Plate the cells in fibronectin-coated wells at $10^{6}$ cells $\mathrm{cm}^{-2}$ in 2-mL MAPC expansion medium (Table 3).

High-density culture of cells for 1 month:

(v) For the first week of culturing, add $1 \mathrm{ml}$ of medium every other day.

(vi) For the second week of culturing, change half of the medium every other day.

(vii) For the third and fourth weeks of culturing, trypsinize 1-2 times a week and replate at $80 \%$ confluence.

Column depletion of $\mathrm{CD}_{4} 5^{+}$cells with MACS microbeads:

(viii) After 4 weeks, trypsinize the cells, centrifuge and count. Label the cells with anti-rat CD45-PE antibody and anti-PE microbeads.

(ix) Run 3-5 × $10^{6}$ cells through a 23-25-gauge needle through the MACS column at the rate of one drop every 4-5 s.

Subcloning, culture and screening for potential MAPC clones:

(x) Plate the eluted cells at five cells per well in a 96 -well plate coated with fibronectin.

(xi) Change half of the medium every other day for 2 weeks.

(xii) After the second week, trypsinize colonies of 30-50 cells and expand them at low density without cell-to-cell contact.

(xiii) Maintain the cells at low density until small clusters of spindle/triangular small cells appear.

(xiv) Expand newly formed clusters at 300 cells $\mathrm{cm}^{-2}$. Detection of cells with MAPC phenotype may require between 2-10 weeks of culture.

(xv) Screen the clones for Oct4 by RT-qPCR or staining.

Adapted from Subramanian et al. ${ }^{1}$.

hepatic genes were minimally induced. This led us to re-evaluate the culture conditions for liver differentiation.

The 20-day differentiation protocol described here is modeled on liver embryonic development (Fig. 1). To mimic Nodal/Cripto signaling and the canonical $\beta$-catenin activity involved in primitive streak (PS) and definitive endoderm (DE) formation, cells were first treated for 6 days with Activin-A and Wnt3a, respectively. Cytokines produced by the cardiac mesenchyme and the septum transversum mesenchyme to induce formation of hepatic endoderm from anterior endoderm were mimicked in vitro by the stimulation of cells with BMP4 and FGF2 for $4 \mathrm{~d}$. A combination of FGFs (FGF1, FGF4 and FGF8) was used to mimic the growth factors that induce liver bud growth (4 d), and finally hepatocyte growth factor (HGF) and Follistatin were used to enhance the maturation of generated hepatoblasts into hepatocyte-like cells ( 6 days). The main difference between this protocol and the previously described protocol is the sequential exposure based on liver embryogenesis. Both cytokines used in the previous protocol (FGF4 and HGF) are incorporated into the current protocol, but are only used from day 10 onward, after two initial steps aimed at mimicking gastrulation and hepatic endoderm formation.

\section{Evaluation of the success of the protocol}

To monitor and evaluate the protocol efficiency, RT-qPCR and immunocytochemistry can be performed. A list of key genes to be evaluated is presented in Box 2, while the primer sequences we have successfully used are listed in Table 1. As a housekeeping gene, we have used Gapdh. We used the Qiagen RNeasy kit for RNA isolation as per the manufacturer's instructions, but alternative methods can be used. As positive controls for RT-qPCR, RNA from rat fetal liver at E15 and isolated adult rat hepatocytes are suitable.
For immunocytochemistry, a list of possible combinations of antibodies for staining at different stages is presented in Box 2, whereas the antibodies, isotypes and fixatives we use are listed in Table 2.

As functional analysis, we chose a combination of secretion (albumin, urea), storage (glycogen) and detoxification capacity (cytochrome P450, glutathione S-transferase (GST), bilirubin conjugation). Albumin secretion is detectable from day 14 onward. Spontaneous urea production can already be found from day 6, but urea production in response to ammonia (urea cycle) is detectable from day 10, becoming maximal by day 20. Many substrates are conjugated to GSH by GST, for example, 1-chloro-2,4-dinitrobenzene (CDNB). Therefore, the formation of GSH-CDNB is used as a quantitative assay to measure total GST activity. Subtypes of GST can be analyzed as well by using ethacrynic acid to measure fetal GST $\pi$ activity and di-chloro-nitrobenzene for more mature GST $\mu$ activity (protocol not shown).

\section{Experimental design}

The differentiation capacity of rMAPCs is unaffected by the passage number (no differences were seen for differentiations carried out between passages 17 and 35 , equivalent to $>100$ population

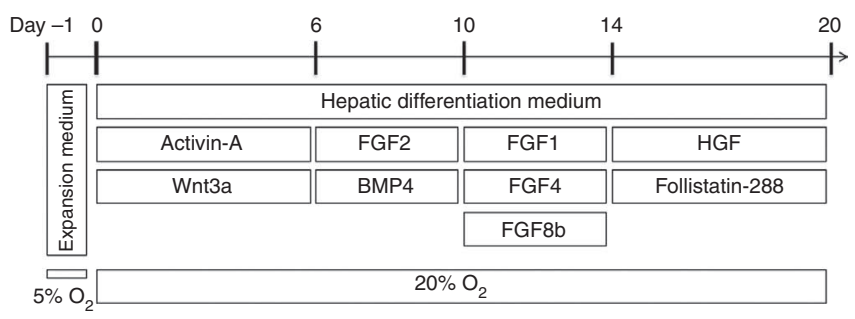

Figure 1 | Overview of the liver differentiation protocol. 


\section{BOX 2 | REAL-TIME RT-qPCR ANALYSIS OF TRANSCRIPTS}

(Items in boldface type are detailed in Fig. 3.)

Undifferentiated MAPCs: Oct4, Foxa2, Sox7, Sox17

Primitive streak/mesendoderm: Eomes, Mixl1, Brachyury, Gsc, E-cadherin

Definitive endoderm: Hex, Mixl1, Cxcr4, Tm4sf2, Lhx1, Gsc, Sox17, E-cadherin

Hepatoblasts: Afp, Ttr, Krt19, Alb

Hepatocytes: Alb, Aat, Tat, G6pc, Adh1C, ApoF, Mrp2, Cps-1, Arg-1, Pepck, Cx32, HepPar1, To, Cyp2b6, Cyp1a2, Cyp7a1, Bsep, GlyS,

Factor $V$

Liver-enriched transcription factors: $H n f 4 \alpha, H n f 1 \alpha, H n f 6$, Prox1, Cebp $\alpha$, Cebp $\beta$

Adapted from Sancho-Bru et al. ${ }^{28}$.

doublings). rMAPCs with higher passage number do accumulate more genetic abnormalities; therefore, most of the cell cultures should be terminated around passage numbers 35-40.

Using the protocol described here, rMAPCs can be efficiently differentiated into PS/mesendoderm (ME)/DE, followed by the acquisition of a hepatoblast phenotype and finally the acquisition of mature hepatocyte characteristics. Freshly isolated rat hepatocytes should be used as positive control for functional assays. Alternatively, immortalized cell lines (such as HepG2) can be used, bearing in mind that gene expression and functionality may differ from primary hepatocytes. As negative control, undifferentiated rMAPCs (day 0) can be used.

Hepatocyte differentiation from rMAPCs as described here is still in an experimental phase and the impurity of the final progeny makes them not yet suitable for toxicological or preclinical studies. However, ongoing studies to scale the current protocols and to purify cells with mature hepatocyte features from the mixed progeny generated using the current protocol may ultimately yield rMAPC hepatocyte progeny with mature functional characteristics similar to those of hepatocytes (metabolization of ammonia to urea, inducible cytochrome activity, bilirubin conjugation), which may be used for in vitro screening purposes including ADMET studies.

\section{Conclusion}

A large number of protocols have been described to differentiate various types of mesenchymal stem cells into hepatocytelike cells ${ }^{20-22}$. In most of these protocols, a sequential exposure or a combination of HGF, FGF and Oncostatin M is used. Obviously, the main focus of these protocols is the generation of hepatocytes, but only little emphasis to developmental milestones such as gastrulation has been paid. Because of the numerous differences between the protocols and the starting cell populations, it is nearly impossible to distinguish which protocol is the best or the most efficient. Besides the generation of functional hepatocyte-like cells, the main benefit of the protocol described here is that it also creates a model to study the early steps of liver embryogenesis. We have not yet determined whether the protocol described here also induces differentiation of MSCs or more primitive cells such as MIAMI, MASCs, BMSCs, USSCs and pre-MSCs among others into hepatocyte-like cells. However, we did demonstrate that, with minimal changes, the protocol that supports rMAPC differentiation into hepatocyte-like cells can also be applied for hepatic differentiation of pluripotent cells, such as human and mouse embryonic and induced pluripotent stem cells, suggesting that cells susceptible to hepatocyte differentiation using the protocol described here should have (near)pluripotent features.

TABLE 1 | Primers.

\begin{tabular}{|c|c|c|}
\hline Genes & Forward sequence & Reverse sequence \\
\hline Aat & 5'-CAAACAAGGTCAGCCATTCTC-3' & 5'-CAGCATCATTGTTGAAGACCC-3' \\
\hline Afp & 5'-ACCTGACAGGGAAGATGGTG-3' & 5'-GCAGTGGTTGATACCGGAGT-3' \\
\hline Alb & 5'-TCTGCACACTCCCAGACAAG-3' & 5'-AGTCACCCATCACCGTCTTC-3' \\
\hline Cxcr4 & 5'-GGATGGTGGTGTTCCAGTTC-3' & 5'-TCCCCACGTAATACGGTAGC-3' \\
\hline Cyp1a2 & 5'-GTCCAGGAACACTATCAAGAC-3' & 5'-ACTGTTTCAAATCCAGCTCC-3' \\
\hline Factor $V$ & 5'-CAATGCCAGATGTAACAGTC-3' & 5'-TGTCAATATAAGCCTGCATCC-3' \\
\hline$G 6 p c$ & 5'-GATTCCGGTGCTTGAATGTC-3' & 5'-AGGTGATGAGACAGTACCTC-3' \\
\hline Gapdh & \multicolumn{2}{|c|}{ TaqMan Rodent GAPDh control reagents (Applied Biosystems, cat. no. 4308313) } \\
\hline Gsc & 5'-CCCGGTTCTGTACTGGTGTC-3' & 5'-CCCACGTCTGGGTACTTTGT-3' \\
\hline Krt19 & 5'-CCACACTACGCAGATCCAGA-3' & 5'-ATGCTGAGCTGAGACTGCAA-3' \\
\hline Mixl1 & 5'-GGGAAGATTTCCTCCATCGT-3' & $5^{\prime}$-CTGAGAACCAGATGTACAGAC-3' \\
\hline Tat & 5'-GGAAGCTAAGGATGTCATTCTG-3' & 5'-GACCTCAATTCCCATAGACTC-3' \\
\hline $\operatorname{Tm} 4 s f 2$ & 5'-CTGAAACTGTATGCCATGTTCC-3' & 5'-ATCTTTGCCGTTGTAGTTCTG-3' \\
\hline Ttr & 5'-CAGCAGTGGTGCTGTAGGAGTA-3' & 5'-GGGTAGAACTGGACACCAAATC-3' \\
\hline
\end{tabular}


TABLE 2 | Antibodies.

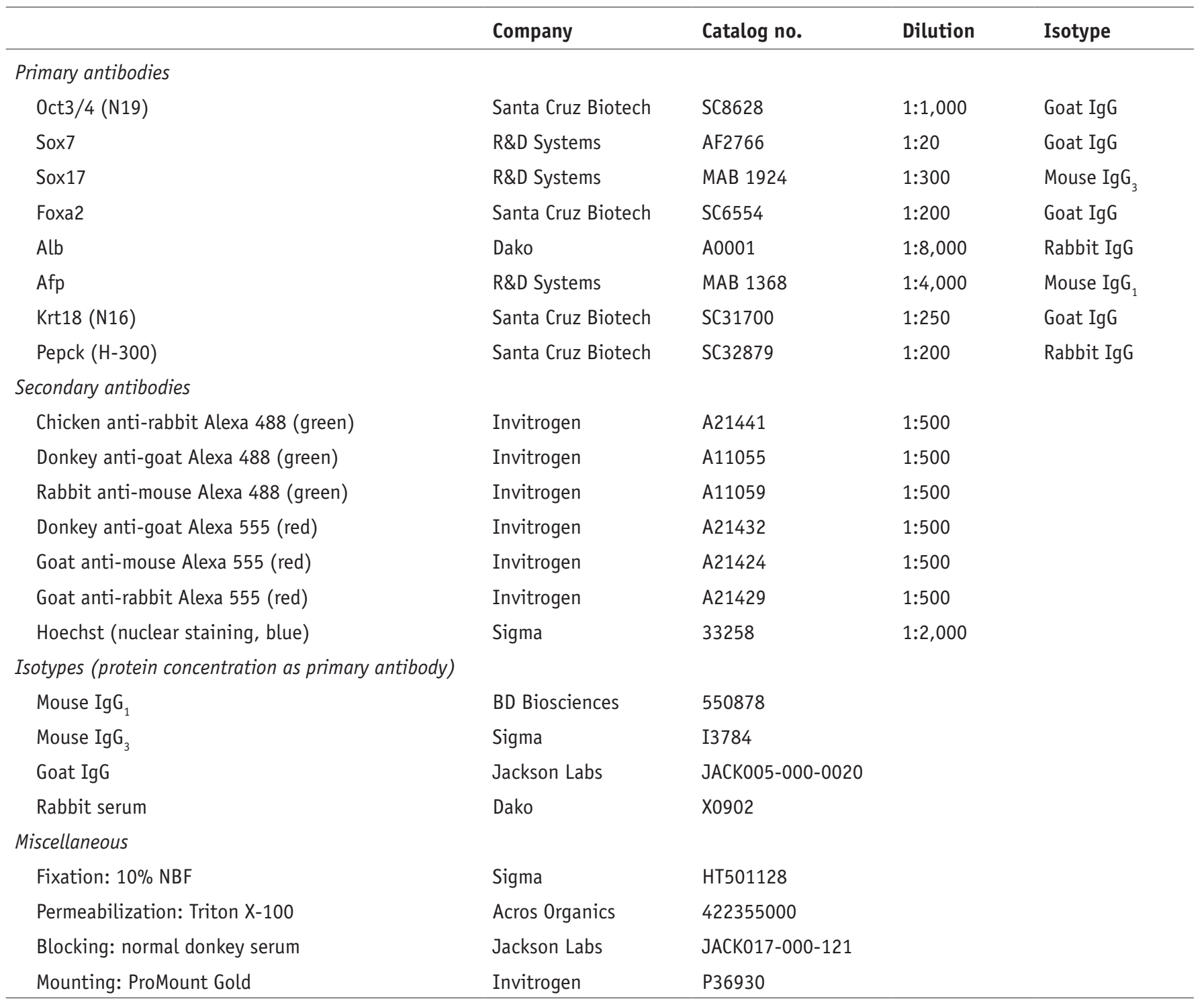

$\mathrm{NBF}$, neutral buffered formalin.

\section{MATERIALS}

\section{REAGENTS}

- Ammonium bicarbonate $\left(\mathrm{NH}_{4} \mathrm{HCO}_{3}\right)$ (Sigma, cat. no. 09830), Step 22, option C only

- Anthrone (Sigma, cat. no. A-1631), Step 22, option B only

- Anti-PE MicroBeads (Miltenyi Biotec, cat. no. 130-048-801)

- Bilirubin (Sigma, cat. no. B4126)

- BSA (Sigma, cat. no. A9418)

- Cell strainer with 40- $\mu \mathrm{m}$ nylon mesh (BD Biosciences, cat. no. 352340)

- Chloroform for HPLC (LabScan, cat. no. PLC05_ _ X) Step 22, option F only! CAUTION Irritating, danger of serious health damage by prolonged exposure through inhalation. Use in a well-ventilated area.

- Collagenase D (Roche, cat. no. 11-088-858-001)

- Cytokines (R\&D Systems): Activin-A (338-AC), BMP4 (314-BP), EGF (2028-3G), FGF1 (232-FA), FGF2 (233-FB), FGF4 (235-F4), FGF8b (423-F8), Follistatin-288 (769-FS), HGF (294-HGN), PDGF-BB (220-BB) and Wnt3a $(1324-\mathrm{WN})$

- Dexamethasone (Sigma, cat. no. D2915)

- DMEM-low glucose (Gibco, cat. no. 31885)
- DNase (Sigma, cat. no. D-4263)

- ELISA Starter Accessory Kit (Bethyl, cat. no. E101-122), Step 22, option A only

- Fibronectin (Sigma, cat. no. F-0635)

- Fetal bovine serum (HyClone, cat. no. CH30160.03)

- Glutathione (GSH) (MP Biomedicals, cat. no. 02101814), Step 22, option E only

- Glycogen (Sigma, cat. no. G-0885), Step 22, option B only

- Growth factor-reduced Matrigel (BD Biosciences, cat. no. 354230)

- Insulin-transferrin-selenium liquid medium supplement (Sigma, cat. no. I-3146)

- Leukemia inhibitory factor $\left(10^{7}\right.$ units $\left.\mathrm{ml}^{-1}\right)$ (Chemicon, cat. no. ESG-1107)

- Linoleic acid-BSA (LA-BSA, $0.845 \mathrm{mg} \mathrm{ml}^{-1} \mathrm{LA}, 100 \mathrm{mg} \mathrm{ml}^{-1} \mathrm{BSA}$ ) (Sigma, cat. no. L-9530)

- MACS separation CS column (Miltenyi Biotec, cat. no. 130-041-305)

- MCDB 201 medium with trace elements, L-glutamine and 30 mM HEPES (MCDB; Sigma, cat. no. M-6770)

- Methanol for HPLC (VWR BPH Prolabo, cat. no. 20837.320), Step 22, option F only 
- Omeprazole (AstraZeneca, cat. no. M130064AB), Step 22, option D only

- PBS pH 7.4 w/o $\mathrm{CaCl}_{2}$ and $\mathrm{MgCl}_{2}$ (Gibco, cat. no. 10010-015)

- PE mouse anti-rat CD45 (BD Pharmingen, cat. no. 554878)

- Penicillin-streptomycin solution (Cellgro, cat. no. 30-002-CI)

- Phenobarbital (Sigma, cat. no. P1636), Step 22, option D only

- Phosphoric acid solution for HPLC $\left(\mathrm{H}_{3} \mathrm{PO}_{4}\right)$ (Fluka, cat. no. 79626), Step 22, option F only

- P450-Glo CYP1A2 Assay (Promega, cat. no. V8771), Step 22, option D only

- QuantiChrom Urea Assay Kit (BioAssay Systems, cat. no. DIUR-500),

Step 22, option C only

- Rat Albumin ELISA Quantitation Set (Bethyl, cat. no. E110-125), Step 22, option A only

- Rat MAPC (see Box 1 for preparation details)

- Tetrabutylammonium hydrogen sulfate (TBA) for HPLC (Acros, cat. no. 42010), Step 22, option F only

- Tris-phosphate-EDTA buffer 0.8 M (Sigma, cat. no. T3154), Step 22, option F only

- Trypsin-EDTA $0.05 \%$ (Gibco, cat. no. 25300)

- Trypsin-EDTA $0.25 \%$ (Gibco, cat. no. 25200)

- White opaque 96-well plates (Thermo Scientific, cat. no. 15042), Step 22, option D only

- Xanthobilirubic acid (prepared according to the method of Grünewald et al. $\left.{ }^{23}\right)$, Step 22, option F only

-1-Chloro-2,4-dinitrobenzene 99\% (CDNB; Acros Organics, cat. no. 16051), Step 22, option E only! CAUTION Very toxic to aquatic organisms, may cause long-term adverse effects in the aquatic environment. Collect waste separately.

-2-Mercaptoethanol $50 \mathrm{nM}$ 1,000× (Gibco, cat. no. 31350)

EQUIPMENT

- Analytical nitrogen evaporator (Organomation, cat. no. N-EVAP 11250),

Step 22, option F only

- BioPhotometer $8.5 \mathrm{~mm}$ (Eppendorf, cat. no. 6131 23861)

- Luminometer (Thermo-Labsystems Fluoroskan Ascent FL)

- Liquid chromatograph (Waters, cat. no. 995 photodiode $+2 \times$ Waters, cat. no. 515 HPLC pump)

- Microplate reader (Bio-Rad, model 3550)

- NucleoCounter + NucleoCassette (Chemometec)

- Spectrophotometer (Shimadzu, cat. no. UV-2101)

- Stericup with Millipore Express PLUS 0.22- $\mu$ m filter (Millipore, cat. no. SCGP U05 RE)

REAGENT SETUP

Matrigel-coated plates Store Matrigel $\left(10\right.$-ml bottle) at $-20^{\circ} \mathrm{C}$. It is advisable to freeze down Matrigel in separate vials of smaller volume (for example, $400 \mu \mathrm{l})$ to avoid unnecessary freeze-thaw cycles. Matrigel polymerizes at room temperature $\left(20^{\circ} \mathrm{C}\right)$, hence it is necessary to thaw the bottle of Matrigel on ice and use frozen pipette tips and cryotubes. If thawed too quickly, Matrigel will partially polymerize and give rise to clumps.

Thaw one vial $(400 \mu \mathrm{l})$ of Matrigel slowly on ice. Dissolve $400 \mu \mathrm{l}$ of Matrigel in $20 \mathrm{ml}$ of ice-cold PBS (final concentration 2\%) and add $1 \mathrm{ml}$ to every well of a 12-well plate or chamber slide. Incubate for at least $30 \mathrm{~min}$ at $37^{\circ} \mathrm{C}$ or for $2-3 \mathrm{~h}$ at room temperature. Use immediately.

MCDB solution Dissolve one vial of MCDB 201 medium (17.7 g) in $1,000 \mathrm{ml}$ of Milli-Q water in a flat-bottom Erlenmeyer flask. Stir with a magnetic stir bar until completely dissolved (yellow suspension). Measure the $\mathrm{pH}$ and adjust with $\mathrm{NaOH}$ or $\mathrm{HCl}$ dropwise until it equals 7.2. Filter the solution using Stericup filter. The solution can be stored at $4{ }^{\circ} \mathrm{C}$ for up to 6 weeks.

0.2\% BSA-PBS solution Dissolve $100 \mathrm{mg}$ of BSA in a final volume of $50 \mathrm{ml}$ of PBS and filter using Stericup filter to produce a $0.2 \%$ BSA-PBS solution. Store at $4{ }^{\circ} \mathrm{C}$ for several weeks.

$\mathbf{0 . 2} \%$ BSA-HCl solution Dilute $200 \mu \mathrm{l}$ of $\mathrm{HCl}$ (stock concentration $2 \mathrm{M}$ ) in $100 \mathrm{ml}$ of distilled water to produce a $4 \mathrm{mM} \mathrm{HCl}$ solution. Dissolve $200 \mathrm{mg}$ of BSA in a final volume of $100 \mathrm{ml}$ of $4 \mathrm{mM} \mathrm{HCl}$ solution. Filter using Stericup filter. Store at $4{ }^{\circ} \mathrm{C}$ for several weeks.

$2 \% \mathrm{KOH}$ solution Dissolve $2 \mathrm{~g}$ of $\mathrm{KOH}$ in a final volume of 100 -ml methanol to produce a $2 \%$ solution. Store at room temperature for several weeks. $60 \mu$ M BSA solution Dissolve $198 \mu \mathrm{g}$ of BSA in $50 \mathrm{ml}$ of hepatic differentiation medium to produce a $60 \mu \mathrm{M}$ BSA solution. Use immediately.

Activin-A solution Dissolve $5 \mu \mathrm{g}$ (one vial) in $500 \mu \mathrm{l}$ of $0.2 \%$ BSA-PBS to produce a 10 -ng $\mu 1^{-1}$ solution. Store at $4{ }^{\circ} \mathrm{C}$ for 1 week or at $-80^{\circ} \mathrm{C}$ for several months.
Anthrone solution Dissolve $2 \mathrm{mg}$ of anthrone in 1,000- $\mu \mathrm{l} \mathrm{H}_{2} \mathrm{SO}_{4}$ to produce a $0.2 \%$ solution (yellow color). Use immediately.

Bilirubin solution Dissolve $17.5 \mathrm{mg}$ of bilirubin in $5 \mathrm{ml}$ DMSO to produce a $6 \mathrm{mM}$ stock solution. Dissolve $250 \mu \mathrm{l}$ of stock solution in $50 \mathrm{ml}$ of $60 \mu \mathrm{M}$ BSA solution to produce a final $30 \mu \mathrm{M}$ bilirubin solution. Use immediately. BMP4 solution Dissolve $10 \mu \mathrm{g}$ (one vial) in $1,000 \mu \mathrm{l}$ of $0.2 \% \mathrm{BSA}-\mathrm{HCl}$ to produce a 10 -ng $\mathrm{\mu l}^{-1}$ solution. Store at $4{ }^{\circ} \mathrm{C}$ for 1 week or at $-80^{\circ} \mathrm{C}$ for several months.

CDNB solution Dissolve $30.4 \mathrm{mg}$ of CDNB in $5 \mathrm{ml}$ of ethanol to produce a $30 \mathrm{mM}$ solution. Use immediately.

Dexamethasone solution Dissolve $100 \mathrm{mg}$ (one bottle) in 1,000 $\mathrm{ml}$ of distilled $\mathrm{H}_{2} \mathrm{O}$ to produce a $0.25 \mathrm{mM}$ solution. Filter using Millipore Express plus a $0.22-\mu \mathrm{m}$ filter. Store at $-20^{\circ} \mathrm{C}$ for several months.

EGF solution Dissolve $1 \mathrm{mg}$ (one vial) in $5 \mathrm{ml}$ of $0.2 \%$ BSA-PBS to produce a 200 -ng $\mu \mathrm{l}^{-1}$ solution. Store at $-80^{\circ} \mathrm{C}$ for several months.

Expansion medium (Table 3) Store at $4{ }^{\circ} \mathrm{C}$ for 1 month.

FGF1 solution Dissolve $25 \mu \mathrm{g}$ (one vial) in $2,500 \mu \mathrm{l}$ of $0.2 \%$ BSA-PBS to produce a 10 -ng $\mu \mathrm{l}^{-1}$ solution. Store at $4{ }^{\circ} \mathrm{C}$ for 1 week or at $-80^{\circ} \mathrm{C}$ for several months.

FGF2 solution Dissolve $25 \mu \mathrm{g}$ (one vial) in $2,500 \mu \mathrm{l}$ of $0.2 \%$ BSA-PBS to produce a 10 -ng $\mu \mathrm{l}^{-1}$ solution. Store at $4{ }^{\circ} \mathrm{C}$ for 1 week or at $-80^{\circ} \mathrm{C}$ for several months.

FGF4 solution Dissolve $25 \mu \mathrm{g}$ (one vial) in $1,000 \mu \mathrm{l}$ of $0.2 \%$ BSA-PBS to produce a 25 -ng $\mu \mathrm{l}^{-1}$ solution. Store at $4{ }^{\circ} \mathrm{C}$ for 1 week or at $-80{ }^{\circ} \mathrm{C}$ for several months.

FGF8b solution Dissolve $25 \mu \mathrm{g}$ (one vial) in $1,000 \mu \mathrm{l}$ of $0.2 \%$ BSA-PBS to produce a 25 -ng $\mu \mathrm{l}^{-1}$ solution. Store at $4{ }^{\circ} \mathrm{C}$ for 1 week or at $-80^{\circ} \mathrm{C}$ for several months.

Fibronectin solution Dissolve $2 \mathrm{mg}$ in $4,000 \mu \mathrm{l}$ of PBS to produce a 500 -ng $\mu 1^{-1}$ stock solution. Dilute $100 \mu$ of stock solution in $500 \mathrm{ml}$ of PBS to produce a final $100-\mathrm{ng} \mathrm{ml}^{-1}$ solution. Filter using Millipore Express plus $0.22-\mu \mathrm{m}$ filter. Store at $4{ }^{\circ} \mathrm{C}$ for several weeks.

Follistatin solution Dissolve $25 \mu \mathrm{g}$ (one vial) in 2,500 $\mu \mathrm{l}$ of $0.2 \%$ BSA-PBS to produce a 10 -ng $\mu 1^{-1}$ solution. Store at $4{ }^{\circ} \mathrm{C}$ for 1 week or at $-80^{\circ} \mathrm{C}$ for several months.

Glycine buffer $\mathbf{p H} 2.4$ Dissolve $15.01 \mathrm{~g}$ in 1,000 $\mathrm{ml}$ of distilled $\mathrm{H}_{2} \mathrm{O}$ to produce a $0.2 \mathrm{M}$ glycine solution. Dilute $10 \mathrm{ml}$ of $\mathrm{HCl}$ (stock concentration $2 \mathrm{M}$ ) in $90 \mathrm{ml}$ of distilled water to produce a $0.2 \mathrm{M} \mathrm{HCl}$ solution. Dilute $50 \mathrm{ml}$ of $0.2 \mathrm{M}$ glycine solution with $32.4 \mathrm{ml}$ of $0.2 \mathrm{M} \mathrm{HCl}$ solution in $117.6 \mathrm{ml}$ of distilled $\mathrm{H}_{2} \mathrm{O}$ to produce a final $50 \mathrm{mM}$ glycine buffer of $\mathrm{pH}$ 2.4. Use immediately.

Glycogen solution Dissolve 1,500 $\mu \mathrm{g}$ of glycogen in 1,500 $\mu \mathrm{l}$ of $\mathrm{H}_{2} \mathrm{O}$ to produce a $1-\mathrm{mg} \mathrm{ml}^{-1}$ solution. Store at $-20^{\circ} \mathrm{C}$ for several months. GSH solution Dissolve $0.384 \mathrm{mg}$ of GSH in $1 \mathrm{ml}$ of phosphate buffer to produce a $1.25 \mathrm{mM}$ solution. Use immediately.

TABLE 3 | Expansion medium (500 ml).

\begin{tabular}{lcc} 
Component & Volume $(\mathrm{ml})$ & Final concentration \\
\hline DMEM-low glucose & 270 & \\
MCDB & 200 & $2 \%$ \\
FBS & 10 & $1 \times$ \\
ITS & 5 & $1 \times$ \\
LA-BSA & 5 & $1 \times$ \\
Penicillin-streptomycin & 5 & $100 \mathrm{nM}^{-1 \times}$ \\
L-Ascorbic acid $(10 \mathrm{mM})$ & 5 & $10 \mathrm{ng} \mathrm{ml}^{-1}$ \\
PDGF-BB $\left(10 \mu \mathrm{gl}^{-1}\right)$ & 0.5 & $50 \mathrm{nM}^{-1}$ \\
Dexamethasone $(0.25 \mathrm{mM})$ & 0.1 & $10^{3} \mathrm{units} \mathrm{ml}^{-1}$ \\
LIF $\left(10^{7}\right.$ units mL $\left.\mathrm{mL}^{-1}\right)$ & 0.05 & $10 \mathrm{ng} \mathrm{ml}^{-1}$ \\
EGF $\left(200 \mu \mathrm{g} \mathrm{m}^{-1}\right)$ & 0.025 &
\end{tabular}

EGF, epidermal growth factor; ITS, insulin-transferrin-selenium; LA-BSA, linoleic acid-BSA; LIF, leukemia inhibitory factor. 
Hepatic differentiation medium (Table 4) Store at $4{ }^{\circ} \mathrm{C}$ for 1 month. HGF solution Dissolve $25 \mu \mathrm{g}$ (one vial) in 2,500 $\mu \mathrm{l}$ of $0.2 \%$ BSA-PBS to produce a 10 -ng $\mu \mathrm{l}^{-1}$ solution. Store at $4{ }^{\circ} \mathrm{C}$ for 1 week or at $-80^{\circ} \mathrm{C}$ for several months. $\mathrm{L}$-Ascorbic acid solution Dissolve $1.45 \mathrm{~g}$ in $500 \mathrm{ml}$ of PBS to produce a $10 \mathrm{mM}$ solution. Stir with a magnetic stir bar for 10-20 $\mathrm{min}$ in the dark and filter using Stericup filter. Store at $-20^{\circ} \mathrm{C}$ for several months.

Omeprazole solution Dissolve $40 \mathrm{mg}$ (one vial) of omeprazole in $10 \mathrm{ml}$ of $0.9 \% \mathrm{NaCl}$ to produce a $4-\mathrm{mg} \mathrm{ml}^{-1}(11.58 \mathrm{mM})$ solution. Store at $-20^{\circ} \mathrm{C}$ for several months.

Platelet-derived growth factor BB solution (PDGF-BB) Dissolve $50 \mu \mathrm{g}$ (one vial) in $5 \mathrm{ml}$ of $0.2 \% \mathrm{BSA}-\mathrm{HCl}$ to produce a $10-\mu \mathrm{g} \mathrm{ml}^{-1}$ solution. Store at $-80^{\circ} \mathrm{C}$ for several months.

Phenobarbital solution Dissolve $5 \mathrm{~g}$ of phenobarbital in $21.52 \mathrm{ml}$ of PBS to produce a $1 \mathrm{M}$ stock solution. Store at $-20^{\circ} \mathrm{C}$ for several months. Dilute $500 \mu \mathrm{l}$ of $1 \mathrm{M}$ stock solution in $9.5 \mathrm{ml}$ of PBS to produce a final $50 \mathrm{mM}$ working solution. Store at $4{ }^{\circ} \mathrm{C}$ for several weeks.

Phosphate buffer pH 6.5 Dissolve $1.7 \mathrm{~g}$ of $\mathrm{KH}_{2} \mathrm{PO}_{4}$ in $100 \mathrm{ml}$ of PBS to produce a $125 \mathrm{mM}$ solution. Measure the $\mathrm{pH}$ and add drops of $\mathrm{KOH}$ until the $\mathrm{pH}$ is 6.5. Use immediately.

Wnt3a solution Dissolve $5 \mu \mathrm{g}$ (one vial) in $500 \mu \mathrm{l}$ of $0.2 \%$ BSA-PBS to produce a 10 -ng ml ${ }^{-1}$ solution. Store at $4{ }^{\circ} \mathrm{C}$ for 1 week or at $-80^{\circ} \mathrm{C}$ for several months. EQUIPMENT SETUP

Microplate reader (albumin secretion, Step 22A, and urea production, Step 22C only) Use dual optical photometric settings with $450 \mathrm{~nm}$ as the first wavelength (samples) and $655 \mathrm{~nm}$ as the second wavelength (background). Spectrophotometer (glycogen storage, Step 22B only) Use the quantitative mode with a wavelength of $620 \mathrm{~nm}$. Create a standard curve with 12 readings (six readings in duplicate), entering the micrograms of glycogen.

Spectrophotometer (GST activity, Step 22E only) Use the time-course mode with a wavelength of $340 \mathrm{~nm}$. Set the number of readings to 7, with a 1-min interval.
TABLE 4 | Hepatic differentiation medium (500 ml).

\begin{tabular}{lcc}
\hline Component & Volume $(\mathrm{ml})$ & Final concentration \\
\hline DMEM-low glucose & 285 & \\
MCDB & 200 & \\
Penicillin-streptomycin & 5 & $1 \times$ \\
L-Ascorbic acid (10 mM) & 5 & $100 \mathrm{nM}$ \\
Dexamethasone $(0.25 \mathrm{mM})$ & 2 & $1 \mu \mathrm{M}$ \\
ITS & 1.25 & $0.25 \times$ \\
LA-BSA & 1.25 & $0.25 \times$ \\
2-Mercaptoethanol $(50 \mathrm{mM})$ & 0.5 & $50 \mu \mathrm{M}$ \\
\hline
\end{tabular}

ITS, insulin-transferrin-selenium; LA-BSA, linoleic acid-BSA.

Luminometer (cytochrome activity, Step 22D only) Start with a shaking step for $1 \mathrm{~min}$ at 300 r.p.m., followed by detection using the kinetic mode. Set the number of readings to 11 , with a 2 -min interval.

High-pressure liquid chromatography (bilirubin conjugation, Step 22F only) Create solvent A ( $66 \mathrm{ml}$ of methanol $+39 \mathrm{ml}$ of Milli-Q water + $160 \mu$ lof TBA, brought to $\mathrm{pH} 7.6$ with $\left.\mathrm{H}_{3} \mathrm{PO}_{4}\right)$ and solvent $\mathrm{B}(75 \mathrm{ml}$ of methanol $+16 \mathrm{ml}$ of Milli-Q water $+10 \mathrm{ml}$ of ethanol $+140 \mu \mathrm{l}$ of TBA + $150 \mu$ lof Tris, brought to $\mathrm{pH} 7.5$ with $\mathrm{H}_{3} \mathrm{PO}_{4}$ ) and connect both bottles to a HPLC pump. Set a continuous solvent flow rate of $1 \mathrm{ml} \mathrm{min}^{-1}$. Start with $100 \%$ solvent $\mathrm{A}-0 \%$ solvent $\mathrm{B}$ mixture and gradually change to $0 \%$ solvent A-100\% solvent B mixture by minute 11 . Continue the same settings for 6 min until minute 17.

\section{PROCEDURE}

\section{Seeding undifferentiated rMAPCs $\bigcirc$ TIMING $1 \mathrm{~h}$ (1 day before differentiation)}

1| Grow and isolate rMAPCs; for further details, see Box 1 (ref. 1). Grow cells in 10-cm dishes until they are $>80 \%$ confluent.

2| Aspirate the expansion medium and rinse the dishes with PBS.

3| To detach the cells, add $1 \mathrm{ml}$ of trypsin $0.25 \%$. Increase the dislodgment of cells by patting the plates gently. Check using a microscope whether all cells are detached.

$\triangle$ CRITICAL STEP Avoid overexposure to trypsin, as this is harmful to the cells. Limit the incubation time to less than 2 min, and do not incubate at $37^{\circ} \mathrm{C}$ during trypsinization.

4| Block trypsin with $2 \mathrm{ml}$ of expansion medium per dish.

5| Aspirate cells in a centrifuge tube and quantify using NucleoCounter.

6| Centrifuge at $700 \mathrm{~g}$ for $6 \mathrm{~min}$.

7| Remove the supernatant and resuspend $10^{6}$ cells in $7.5 \mathrm{ml}$ of expansion medium.

8| Remove $2 \%$ Matrigel solution from wells of a 12-well Matrigel-coated plate (prepared as detailed in REAGENT SETUP).

9| Add $1.5 \mathrm{ml}$ of cell suspension to every well (200,000 cells per well, density 52,600 cells cm$\left.{ }^{-2}\right)$.

10| Store in a $5 \% \mathrm{O}_{2}-5.8 \% \mathrm{CO}_{2}-37{ }^{\circ} \mathrm{C}$ incubator until cells become $80-90 \%$ confluent (usually after $12-24 \mathrm{~h}$ ).

$\triangle$ CRITICAL STEP rMAPCs need to be confluent when initiating differentiation cultures, hence it is important not to start the first step of differentiation too quickly after plating the cells. 
$\triangle$ CRITICAL STEP Ensure that floating cells are washed away carefully because they may have a negative impact on the first days of differentiation.

12 Add $1.5 \mathrm{ml}$ of differentiation medium containing $15 \mu \mathrm{l}$ of Activin-A solution (final concentration $100 \mathrm{ng} \mathrm{ml}^{-1}$ ) and $7.5 \mu \mathrm{l}$ of Wnt3a solution (final concentration $50 \mathrm{ng} \mathrm{ml}^{-1}$ ) per well. Store in a $21 \% \mathrm{O}_{2}-5.8 \% \mathrm{CO}_{2}-37{ }^{\circ} \mathrm{C}$ incubator until day 2.

13| On day 2, remove $950 \mu \mathrm{l}$ of medium and add $1,000 \mu \mathrm{l}$ of differentiation medium containing $10 \mu \mathrm{l}$ of Activin-A solution and $5 \mu \mathrm{l}$ of Wnt3a solution. Store in a $21 \% \mathrm{O}_{2}-5.8 \% \mathrm{CO}_{2}-37{ }^{\circ} \mathrm{C}$ incubator until day 4.

14| 0 n day 4, remove $950 \mu \mathrm{l}$ of medium and add $1,000 \mu \mathrm{l}$ of differentiation medium containing $10 \mu \mathrm{l}$ of Activin-A solution and $5 \mu \mathrm{l}$ of Wnt3a solution. Store in a $21 \% \mathrm{O}_{2}-5.8 \% \mathrm{CO}_{2}-37{ }^{\circ} \mathrm{C}$ incubator until day 6 .

15 On day 6 , remove all medium. Rinse with PBS. Add $1.5 \mathrm{ml}$ of differentiation medium containing $1.5 \mu \mathrm{l}$ of FGF2 solution (final concentration $10 \mathrm{ng} \mathrm{ml}^{-1}$ ) and $7.5 \mu \mathrm{l}$ of BMP4 solution (final concentration $50 \mathrm{ng} \mathrm{ml}^{-1}$ ). Store in a $21 \%$ $\mathrm{O}_{2}-5.8 \% \mathrm{CO}_{2}-37{ }^{\circ} \mathrm{C}$ incubator until day 8 . If desired, retain the samples for further analysis (see Step 22).

16| On day 8 , remove $950 \mu \mathrm{L}$ of medium and add $1,000 \mu \mathrm{l}$ of differentiation medium containing $1 \mu \mathrm{L}$ of FGF2 solution and $5 \mu \mathrm{l}$ of BMP4 solution. Store in a $21 \% \mathrm{O}_{2}-5.8 \% \mathrm{CO}_{2}-37{ }^{\circ} \mathrm{C}$ incubator until day 10.

17| On day 10, remove all medium. Rinse with PBS. Add $1.5 \mathrm{ml}$ of differentiation medium containing $3 \mu \mathrm{l}$ of FGF1 solution (final concentration $20 \mathrm{ng} \mathrm{ml}^{-1}$ ), $1.5 \mu \mathrm{l}$ of FGF8b solution (final concentration $25 \mathrm{ng} \mathrm{ml}^{-1}$ ) and $0.6 \mu \mathrm{l}$ of FGF4 solution (final concentration $10 \mathrm{ng} \mathrm{ml}^{-1}$ ). Store in $21 \% \mathrm{O}_{2}-5.8 \% \mathrm{CO}_{2}-37{ }^{\circ} \mathrm{C}$ incubator until day 12 . If desired, retain samples for further analysis (see Step 22).

18| On day 12, remove $950 \mu \mathrm{l}$ of medium and add $1,000 \mu$ l of differentiation medium containing $2 \mu$ of FGF1 solution, $1 \mu \mathrm{l}$ of FGF8b solution and $0.4 \mu \mathrm{l}$ of FGF4 solution. Store in a $21 \% \mathrm{O}_{2}-5.8 \% \mathrm{CO}_{2}-37{ }^{\circ} \mathrm{C}$ incubator until day 14 .

19| On day 14, remove all medium. Rinse with PBS. Add $1.5 \mathrm{ml}$ of differentiation medium containing $3 \mu \mathrm{l}$ of HGF solution (final concentration $20 \mathrm{ng} \mathrm{ml}^{-1}$ ) and $15 \mu \mathrm{l}$ of Follistatin-288 solution (final concentration $100 \mathrm{ng} \mathrm{ml}^{-1}$ ). Store in $21 \% \mathrm{O}_{2}-5.8 \% \mathrm{CO}_{2}-37{ }^{\circ} \mathrm{C}$ incubator until day 16 . If desired, retain the samples for further analysis (see Step 22).

20| On day 16, remove $950 \mu \mathrm{l}$ of medium and add $1,000 \mu \mathrm{l}$ of differentiation medium containing $2 \mu \mathrm{L}$ of HGF solution and $10 \mu \mathrm{l}$ of Follistatin-288 solution. Store in a $21 \% \mathrm{O}_{2}-5.8 \% \mathrm{CO}_{2}-37{ }^{\circ} \mathrm{C}$ incubator until day 18.

21 0 n day 18 , remove $950 \mu \mathrm{l}$ of medium and add $1,000 \mu \mathrm{l}$ of differentiation medium containing $2 \mu \mathrm{l}$ of HGF solution and $10 \mu \mathrm{l}$ of Follistatin-288 solution. Store in a $21 \% \mathrm{O}_{2}-5.8 \% \mathrm{CO}_{2}-37{ }^{\circ} \mathrm{C}$ incubator until day 20.

22 On day 20, analyze the hepatocyte characteristics. A single test cannot effectively evaluate the hepatocyte characteristics of MAPC progeny. It is important to assess the gene expression profile, as well as protein synthesis and functional analysis, of the cells. This can be carried out in a number of ways: real-time RT-qPCR (Box 2), immunocytochemistry (Box 3), ultrastructural evaluation of hepatocyte cells (electron microscopy, data not shown) or by functional analysis (options A-F) of albumin secretion (option A), glycogen storage as per the spectrophotometrical method of Seifter et al. ${ }^{24}$ (option B), urea production (option C), determination of cytochrome P450 subtype Cyp1a1/1a2 activity (option D), determination of GST activity according to the spectrophotometrical method of Habig et al. ${ }^{25}$ (option E) and/or bilirubin conjugation by HPLC according to the method of Muraca and Blanckaert ${ }^{26}$ (option F).

\section{(A) Albumin secretion $\bigcirc$ TIMING $5 \mathrm{~h}$}

(i) Collect the supernatant from desired time points in $1.5-\mathrm{ml}$ tubes.

(ii) Centrifuge at $>8,000 \mathrm{~g}$ for $1 \mathrm{~min}$.

- PAUSE POINT Use immediately or store at $-20^{\circ} \mathrm{C}$.

(iii) Proceed as indicated by the manufacturer (step 1, capture the antibody for $60 \mathrm{~min}$; step 2, use the blocking solution for $30 \mathrm{~min}$; step 3, dilute the samples at 1:40 and use the standard solution for $60 \mathrm{~min}$; step 4, use the HRP detection antibody (part of the Rat Albumin ELISA Quantitation Set (see REAGENTS)) for 60 min; step 5, TMB (TMB-peroxidase solution; part of the ELISA Starter Accessory Kit (see REAGENTS)) for 15 min; step 6, $\mathrm{H}_{2} \mathrm{SO}_{4}$ ).

(iv) Read the OD on a microplate reader at a wavelength of $450 \mathrm{~nm}$ (specific for TMB). Determine the average OD of duplicate wells and subtract the $0 D_{\text {medium }}$ from all samples.

(v) Create a four-parameter standard curve $\left(y=a x^{3}+b x^{2}+c x+d\right)$ by plotting $0 \mathrm{D}_{\text {standard }}$ on the $x$ axis and $\log \left(\operatorname{Conc}_{\text {standard }}\right)$ on the $y$ axis (log scale is used to ensure that no negative values are obtained). 


\section{BOX 3 | IMMUNOCYTOCHEMISTRY EVALUATION OF PROTEIN EXPRESSION}

(i) Fix the cells in wells using $10 \%$ neutral buffered formalin (NBF)

(ii) Permeabilize cells with PBST ( $0.2 \%$ Triton in PBS) containing 3-5\% serum of the secondary antibody for blocking. Alternatively, donkey serum can be used.

(iii) Incubate overnight at $4{ }^{\circ} \mathrm{C}$ with primary antibodies and the respective isotypes (diluted in PBST containing 3-5\% serum).

(iv) Incubate with secondary antibodies and nuclear counter stain

(v) Mount slides and store at $4^{\circ} \mathrm{C}$ in the dark

(vi) Possible combinations are (items in boldface type are detailed in Fig. 4) Undifferentiated rMAPCs: Cct $^{+} /$Foxa2 $^{+} /$Sox $7^{+} /$Sox $17^{+}$ Hepatoblast and fetal hepatocyte stage: $0 \mathrm{ct4}^{-} / \mathrm{Afp}^{+} / \mathrm{Alb}^{+}, \mathrm{Krt18}^{+}$ More mature hepatocyte-like cells: $\mathrm{Afp}^{-} / \mathrm{Alb}^{+}, \mathrm{Aat}^{+}, \mathrm{Mrp2}^{+}, \mathrm{Pepck}^{+}$ Liver-enriched transcription factors: $\mathrm{Hnf}_{4} \mathrm{\alpha}^{+}$

Adapted from Sancho-Bru et al. ${ }^{28}$.

(vi) Calculate $\log \left(\right.$ Conc $\left._{\text {sample }}\right)$ by using $0 \mathrm{D}_{\text {sample }}$ in the standard curve equation.

(vii) To obtain the final concentration, calculate 10 to the power $\log \left(\operatorname{Conc}_{\text {sample }}\right)$ and multiply by 40 (dilution correction). Results are depicted as $\mathrm{ng} \mathrm{ml}^{-1}$.

Standard curve: $y=a x^{3}+b x^{2}+c x+d$

$$
\text { Albumin }_{\text {sample }}=40^{*} 10^{\wedge}\left[a^{*}\left(0 \mathrm{D}_{\text {sample }}\right)^{3}+b^{*}\left(0 \mathrm{D}_{\text {sample }}\right)^{2}+c^{*}\left(0 \mathrm{D}_{\text {sample }}\right)+d\right]
$$

(B) Glycogen storage $\bigcirc$ TIMING 3-4 h

(i) At the desired time point, remove the supernatant from the wells of interest and rinse with PBS. If required, different concentrations of glucose in the medium can be added, as this will influence the amount of stored glycogen (see Anticipated results).

(ii) Add $500 \mu \mathrm{l}$ of trypsin $0.05 \%$ until the cells detach.

(iii) Add 1,000 $\mu \mathrm{l}$ of medium/supernatant to block trypsin.

(iv) Scrape the bottom of wells with the tip of a 1,000- $\mu$ pipette or cell scraper to ensure that all cells are collected.

(v) Pipette the cell suspension in a 1.5-ml tube and centrifuge at 2,100 $\mathrm{g}$ for $6 \mathrm{~min}$.

(vi) Remove the supernatant and resuspend the pellet in $200 \mu \mathrm{l}$ of distilled $\mathrm{H}_{2} \mathrm{O}$ to create a homogenous cell suspension. PAUSE POINT Samples can be stored at $-80^{\circ} \mathrm{C}$ for several weeks.

(vii) Pipette $60 \mu \mathrm{l}$ of the cell suspension in a $1.5-\mathrm{ml}$ tube with a screw top. Store the remaining cell suspension at $-20{ }^{\circ} \mathrm{C}$ for protein analysis.

(viii) Add $240 \mu \mathrm{l}$ of $33 \% \mathrm{KOH}$ solution to the tube and screw the top tightly.

(ix) Heat the tube to $100{ }^{\circ} \mathrm{C}$ in heating block for $20 \mathrm{~min}$.

(x) Cool the tube in ice water.

(xi) Pipette $125 \mu \mathrm{l}$ of the sample- $\mathrm{KOH}$ suspension in a $15-\mathrm{ml}$ tube in duplicate.

(xii) Pipette $875 \mu \mathrm{l}$ of $\mathrm{H}_{2} \mathrm{O}$ to each $15-\mathrm{ml}$ tube (total volume $1 \mathrm{ml}$ ).

(xiii) Prepare the standard curve by bringing $0,1,2,3,5$ and $10 \mu \mathrm{l}$ of a 1-mg $\mathrm{ml}^{-1}$ glycogen solution to a total volume of $1 \mathrm{ml}$ with $\mathrm{H}_{2} \mathrm{O}$ in a $15-\mathrm{ml}$ tube.

(xiv) Slowly pipette $2 \mathrm{ml}$ of yellow anthrone solution to all tubes.

! CAUTION Adding $\mathrm{H}_{2} \mathrm{SO}_{4}$ to $\mathrm{H}_{2} \mathrm{O}$ results in a strong exothermic reaction, which may spatter if added too quickly.

The bottom of the tube will heat up and may cause burns. Wear protective glasses, clothes and gloves.

(xv) Vortex the tubes. The color of the standard curve changes from yellow to dark green. Because of the reaction with glycogen, the solution is slightly viscous (the darker the color, the higher the viscosity, and the higher the glycogen content).

(xvi) Leave for $10 \mathrm{~min}$, vortex again.

(xvii) Read the OD at $620 \mathrm{~nm}$ (1 ml per cuvette) starting with a standard curve with known content (0-1-2-3-5-10 $\mu \mathrm{g})$. The readout of the samples provides you with the glycogen content in the tube $(\mu \mathrm{g})$.

(xviii) Multiply the glycogen content by 40 (correction for $\mathrm{KOH}$ and $\mathrm{H}_{2} \mathrm{O}$-anthrone dilution) to obtain the glycogen concentration in the primary cell suspension $\left(\mu \mathrm{g} \mathrm{ml}^{-1}\right)$

Standard curve: $y=a x+b$

Glycogen $_{\text {sample }}=40 *\left[a * 0 D_{\text {sample }}+b\right]$

(xix) To compare samples, quantify the total protein content by using the spectrophotometrical method of Bradford et al. ${ }^{27}$. Alternative methods can be used. 
(xx) Divide the glycogen concentration $\left(\mu \mathrm{gl}^{-1}\right)$ by the protein concentration $\left(\mathrm{mg} \mathrm{ml}^{-1}\right)$. The results can be displayed as $\mu \mathrm{g}$ glycogen per $\mathrm{mg}$ protein or as nmol glucose per $\mathrm{mg}$ protein (dividing the glycogen concentration by the molecular mass of glucose, $180.16 \mathrm{~g} \mathrm{~mol}^{-1}$ ).

(C) Urea production in relation to ammonia TIMING $1 \mathrm{~h}$ plus $24 \mathrm{~h}$ incubation before assay

(i) At the desired time point, remove the supernatant from the wells of interest and wash the wells with PBS.

(ii) Add $1,000 \mu \mathrm{l}$ of differentiation medium containing 0 or $1 \mathrm{mM}$ of ammonium bicarbonate $\left(\mathrm{NH}_{4} \mathrm{HCO}_{3}\right)$. Use one well containing $1 \mathrm{mM}$ of sodium bicarbonate $\left(\mathrm{NaHCO}_{3}\right)$ as control for increased alkalosis.

$\triangle$ CRITICAL STEP Do not use $\mathrm{NH}_{4} \mathrm{Cl}$, as this will make the medium slightly more acidic. Acidosis inhibits the production of urea. If $\mathrm{NH}_{4} \mathrm{HCO}_{3}$ is used, always use $1 \mathrm{mM}$ of $\mathrm{NaHCO}_{3}$ in the control well to normalize for the relative alkalosis.

(iii) After $24 \mathrm{~h}$, collect the supernatant in a $1.5-\mathrm{ml}$ tube and replace with normal differentiation medium.

- PAUSE POINT Use immediately or store samples at $-20^{\circ} \mathrm{C}$ until further use.

(iv) Transfer $50 \mu$ of supernatant in duplicate to a transparent 96 -well plate.

(v) Dilute the internal standard to $1: 10$ with $\mathrm{H}_{2} 0$ to a final concentration of $5 \mu \mathrm{g} \mathrm{ml}^{-1}$. Transfer $50 \mu \mathrm{l}$ of internal standard in duplicate to a transparent 96-well plate.

(vi) Transfer $50 \mu \mathrm{l}$ of fresh hepatic differentiation medium in duplicate to a transparent 96 -well plate.

(vii) Mix an equal volume of QuantiChrom Urea Assay Kit Reagents A and B.

(viii) Add $200 \mu \mathrm{l}$ of reagent mix to every well.

(ix) Transfer $50 \mu$ l of supernatant in duplicate to a transparent 96-well plate.

(x) Incubate at room temperature for 50 min.

$\triangle$ CRITICAL STEP Unlike with classical ELISA, there is no termination of the reaction. Ensure that absorbance is read no later than 50 min after adding the reagents.

(xi) Read the absorbance at $450 \mathrm{~nm}$.

(xii) Subtract the result of the medium from every sample. Divide by absorbance of the internal standard and multiply by 5 to obtain the final result, which is given in $\mu \mathrm{g} \mathrm{ml}^{-1}$.

$$
\text { Urea }_{\text {sample }}=\left[\left(\mathrm{Abs}_{\text {sample }}-\mathrm{Abs}_{\text {medium }}\right) / \mathrm{Abs}_{\text {internal standard }}\right]^{*} 5
$$

\section{(D) Cytochrome P450 activity TIMING $6 \mathrm{~h}$ plus $24 \mathrm{~h}$ incubation before assay}

(i) To study the induction at a desired time point, add $10 \mu \mathrm{M}$ of omeprazole $(1.3 \mu \mathrm{l}$ of stock solution $)$ or $500 \mu \mathrm{M}$ of phenobarbital ( $10 \mu \mathrm{l}$ of working solution) to the differentiation medium $24 \mathrm{~h}$ before the assay to the wells to be evaluated. As omeprazole is stable only for $12 \mathrm{~h}$, repeat the process $12 \mathrm{~h}$ before the assay. Always use one well as negative control by adding 1.3 or $10 \mu \mathrm{l}$ of PBS, respectively, to the differentiation medium.

(ii) At the desired time point, remove the supernatant and rinse well with PBS.

$\triangle$ CRITICAL STEP Wash well because omeprazole and phenobarbital degradation products may interfere with the luciferase assay.

(iii) Pipette $400 \mu \mathrm{l}$ of hepatic differentiation medium into every well, including one well without cells (background luminescence).

(iv) Add $8 \mu$ l of luminogenic substrate (Luciferin-ME specific for Cyp1a1/1a2) to every well.

(v) Store in $21 \% \mathrm{O}_{2}-5.8 \% \mathrm{CO}_{2}-37^{\circ} \mathrm{C}$ incubator for $4 \mathrm{~h}$.

(vi) Collect supernatant, replace with $500 \mu \mathrm{l}$ of medium (to keep the cells from drying).

(vii) Transfer $50 \mu \mathrm{l}$ of supernatant to a white opaque 96 -well plate in triplicate.

(viii) Add $50 \mu$ l of Luciferin Detection Reagent to every well.

(ix) Read the luminescence (11 consecutive time points with a 2-min interval, total $22 \mathrm{~min}$ ). In the meantime, remove all medium and add $500 \mu \mathrm{l}$ of trypsin $0.05 \%$ to the wells until the cells detach.

(x) Add 1,000 $\mu \mathrm{l}$ of the medium or supernatant to block the trypsin.

(xi) Scrape the bottom of wells with the tip of a 1,000- $\mu$ l pipette or cell scraper to ensure that all cells are collected.

(xii) Count the cells.

(xiii) Determine the average signal of 11 time points $\left(\operatorname{Lumin}_{\text {sample }}\right)$ and subtract Lumin ${ }_{\text {medium }}$ from the samples to obtain the net signal.

(xiv) To normalize for the different cell number, multiply the net signal by $10^{6}$ and divide by the number of cells. Results are now depicted as cytochrome activity per million cells. As the results are presented in relative light units, scaling can be performed easily. In induction studies, results can also be depicted as fold increase.

$$
\begin{aligned}
& \text { Cyp1a2 }_{\text {activity }} \text { sample } \\
& =1,000,000 *\left(\text { Lumin }_{\text {sample }}-\operatorname{Lumin}_{\text {medium }}\right) / \text { cell number } \\
& \text { Increase }=\text { activity }_{\text {day } 20} / \text { activity }_{\text {day } 14} \text { or activity } \text { induction }_{\text {activity }} \text { no induction }
\end{aligned}
$$

(E) GST activity $\bigcirc$ TIMING $1 \mathrm{~h}$

(i) At the desired time point, remove the supernatant from the wells of interest and rinse with PBS. 
(ii) Add $500 \mu$ l of trypsin $0.05 \%$ until the cells detach.

(iii) Add 1,000 $\mu \mathrm{l}$ of medium/supernatant to block trypsin.

(iv) Scrape the bottom of the wells with the tip of a 1,000- $\mu$ l pipette to ensure that all cells are collected.

(v) Collect the cell suspension in a 1.5-ml tube and centrifuge at 2,100 $\mathrm{g}$ for $6 \mathrm{~min}$.

(vi) Remove the supernatant and resuspend the pellet in $300 \mu \mathrm{l}$ of PBS to create a homogenous cell suspension.

PAUSE POINT Samples can be stored at $-80{ }^{\circ} \mathrm{C}$ for several weeks.

(vii) Add $600 \mu \mathrm{l}$ of GSH solution and $25 \mu \mathrm{l}$ of CDNB solution to the cuvette.

(viii) Add $125 \mu \mathrm{l}$ of cell suspension to the cuvette, mix well. Use $125 \mu \mathrm{l}$ of PBS as negative control.

(ix) Read the absorbance at $340 \mathrm{~nm}$ (formation of the CDNB-GSH conjugate) for $6 \mathrm{~min}$ with a 1-min interval (seven readings).

(x) Only the linear part of the reaction should be used to calculate the GST activity. Therefore, subtract the absorbance at minute $2\left(\mathrm{Abs}_{2 \min }\right)$ from the absorbance at minute $6\left(\mathrm{Abs}_{6 \min }\right)$ to define the difference in absorbance $(\triangle \mathrm{Abs})$.

(xi) Subtract $\triangle \mathrm{Abs}_{\mathrm{PBS}}$ from $\triangle \mathrm{Abs}_{\text {sample }}$.

(xii) Divide $\triangle A$ bs by 4 ( $\triangle$ Abs per minute) and divide by the extinction coefficient of CDNB, namely, $9.6 \mathrm{mM}^{-1}$ (results depicted as $\mu \mathrm{M}$ per min GSH-CDNB). Multiply by 750 to obtain the activity as nmol per min GSH-CDNB

$$
\begin{aligned}
& \Delta \mathrm{Abs}_{\text {sample } / \mathrm{PBS}}=\mathrm{Abs}_{\text {sample }} / \mathrm{PBS} 6 \mathrm{~min}-\mathrm{Abs}_{\text {sample }} / \mathrm{PBS} 2 \mathrm{~min} \\
& \text { Total GST activity } \text { sample }=750 \mathrm{ml}^{*}\left[\left(\Delta \mathrm{Abs}_{\text {sample }}-\Delta \mathrm{Abs}_{\mathrm{PBS}}\right) / 4\right] / 9.6 \mathrm{mM}^{-1}
\end{aligned}
$$

(xiii) To compare samples, quantify the total protein content using either the spectrophotometrical method of Bradford ${ }^{27}$ or alternative methods.

(xiv) Divide the amount of GSH-CDNB by the protein concentration $\left(\mathrm{mg} \mathrm{ml}^{-1}\right)$. The results can be displayed as $\mathrm{nmol}$ GSH-CDNB per mg protein per min.

(F) Bilirubin conjugation TIMING 2-3 h (up to $33 \mathrm{~h}$ of sample harvesting)

(i) At the desired time point, remove the supernatant from the wells of interest and rinse with PBS.

(ii) Add 1,000 $\mu \mathrm{l}$ of bilirubin solution to the wells of interest and to one empty well (first negative control). Add 1,000 $\mu \mathrm{l}$ of 60- $\mu$ M BSA solution to one well containing cells as a second negative control.

$\triangle$ CRITICAL STEP As bilirubin is light sensitive, it is important to work in a dim-light environment.

(iii) Harvest the supernatant at different time points (6, 12, 24 and $33 \mathrm{~h}$ ).

PAUSE POINT Samples can be stored at $-80^{\circ} \mathrm{C}$ for a maximum of 1 month.

(iv) Place $500 \mu \mathrm{l}$ of sample in 10-ml glass tubes with ground-glass stoppers.

(v) Add $60 \mathrm{mg}$ of ascorbic acid and $2 \mathrm{mg}$ of disodium EDTA.

(vi) Add $2 \mathrm{ml}$ of internal standard solution (xanthobilirubinic acid methyl ester $2 \mu \mathrm{g} \mathrm{ml}^{-1}$ ).

(vii) Add $6 \mathrm{ml}$ of $2 \% \mathrm{KOH}$ solution.

(viii) Vortex and incubate the mixture for 60-90 s.

(ix) Add $6 \mathrm{ml}$ of chloroform and $12 \mathrm{ml}$ of glycine buffer.

(x) Shake briefly and centrifuge at $1,000 \mathrm{~g}$ for $10 \mathrm{~min}$.

(xi) Transfer the organic phase (bottom chloroform layer) to a dry $10-\mathrm{ml}$ conical tube.

(xii) Evaporate at $50^{\circ} \mathrm{C}$ under a $\mathrm{N}_{2}$ stream.

- PAUSE POINT The residue can be stored at $-20^{\circ} \mathrm{C}$ for 2 weeks.

(xiii) Dissolve the residue in $10 \mu \mathrm{l}$ of chloroform and $100 \mu \mathrm{l}$ of DMSO shortly before analysis, shake briefly.

(xiv) Inject $10 \mu \mathrm{l}$ into the liquid chromatograph. Separate the pigments by eluting the column at a solvent rate of $1 \mathrm{ml} \mathrm{min}{ }^{-1}$ with a linear gradient over $17 \mathrm{~min}$. Monitor the absorbance at $436 \mathrm{~nm}$.

(xv) In case of doubt (for example, heme interference in control samples), analyze the different peaks by using spectrum analysis. The internal standard has a peak emission at $413 \mathrm{~nm}$, bilirubin around $450 \mathrm{~nm}$ and heme at $405 \mathrm{~nm}$.

(xvi) Normalize the equation for different volumes (volume internal standard $2 \mathrm{ml}$, volume of the sample $0.5 \mathrm{ml}$ ) and compare with the concentration of the internal standard $\left(2 \mu \mathrm{g} \mathrm{m}^{-1}\right)$. To carry this out, multiply the equation of the areas by 8 and by the pigment-dependent factor F. Depict results as $\mu \mathrm{g} \mathrm{ml}^{-1}$. The results can also be depicted as \% decrease in unconjugated bilirubin or \% conjugation of bilirubin into mono/diconjugate.

Bilirubin pigment concentration $=8{ }^{*} F^{*} A_{\text {pigment }} / A_{\text {IS }}$

where $A_{\text {pigment }}$ is the peak area of the pigment, $A_{\mathrm{IS}}$ the peak area of internal standard, $F$ the pigment-dependent factor, unconjugated bilirubin $F=1.102$, bilirubin monoconjugate $F=1.279$, bilirubin diconjugate $F=1.329$.

\section{TIMING}

Steps 1-10, Seeding undifferentiated rMAPCs: 1 h (1 day before differentiation)

Steps 11-21, Hepatocyte differentiation: 20 days 
Figure 2 | Bright field microscopy of rMAPC progeny during liver differentiation. Undifferentiated rMAPCs are round to spindle shaped. On plating at high density they become more triangular and square (days 2-4). During the later stages of differentiation, clusters of round, densely packed cells appear together with more cobblestone-like cells. By day 20, the cells are more rectangular with clear nuclei (scale bar, $100 \mu \mathrm{m})$.

Step 22 option A, Albumin secretion: $5 \mathrm{~h}$ Step 22 option B, Glycogen storage: 3-4 h

Step 22 option C, Urea production: $1 \mathrm{~h}$ (24-h incubation before assay) Step 22 option D, Cytochrome P450 activity: $6 \mathrm{~h}$ (24-h incubation before assay)

Step 22 option E, GST activity: $1 \mathrm{~h}$ Step 22 option F, Bilirubin conjugation: $2-3 \mathrm{~h}$ (up to $33 \mathrm{~h}$ of sample harvesting)
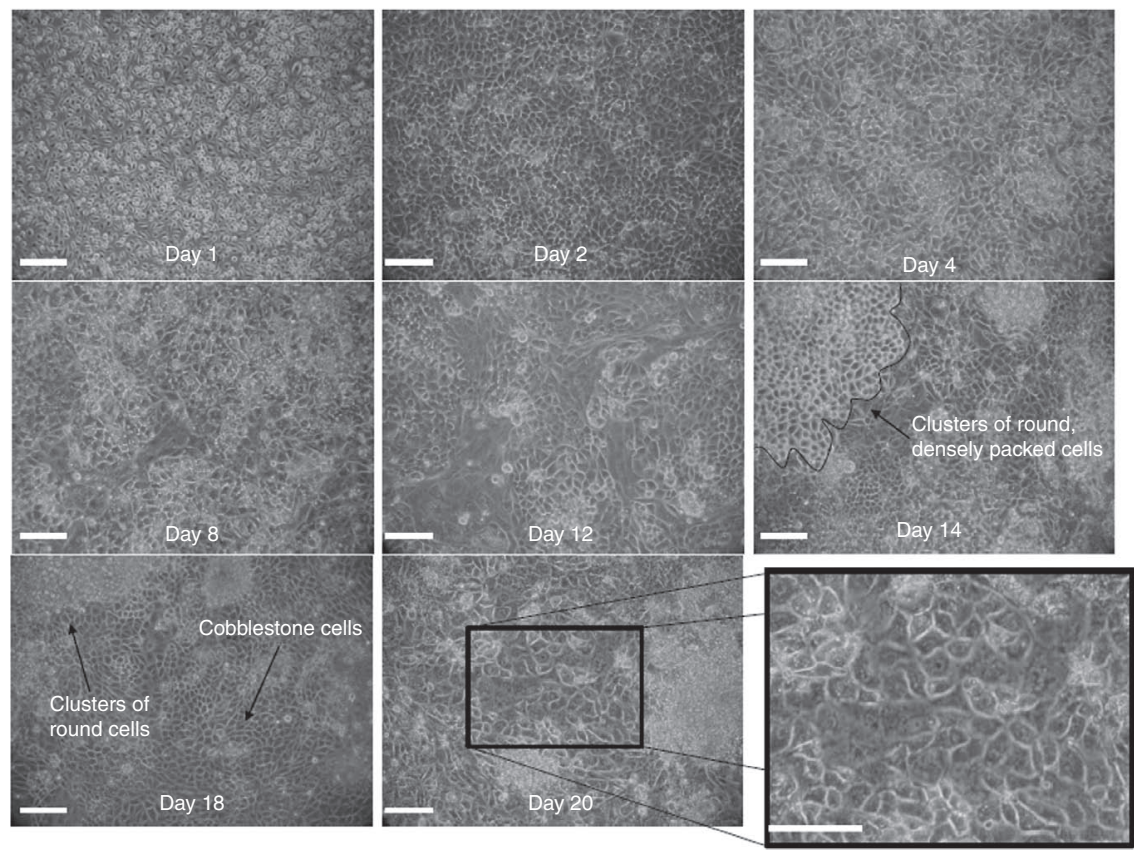

\section{ANTICIPATED RESULTS}

To ensure that differentiation has been performed correctly, it is important to monitor the acquisition of the correct phenotype for each of the embryonic stages of liver differentiation. Morphological changes can be visualized easily with bright field microscopy (Fig. 2).

As indicated in the detailed protocol section, samples are taken for RNA analysis and functional assays at $6,10,14$ and 20 days. No single gene or test can efficiently identify the phenotype acquired by the stem cell progeny. In Boxes 2

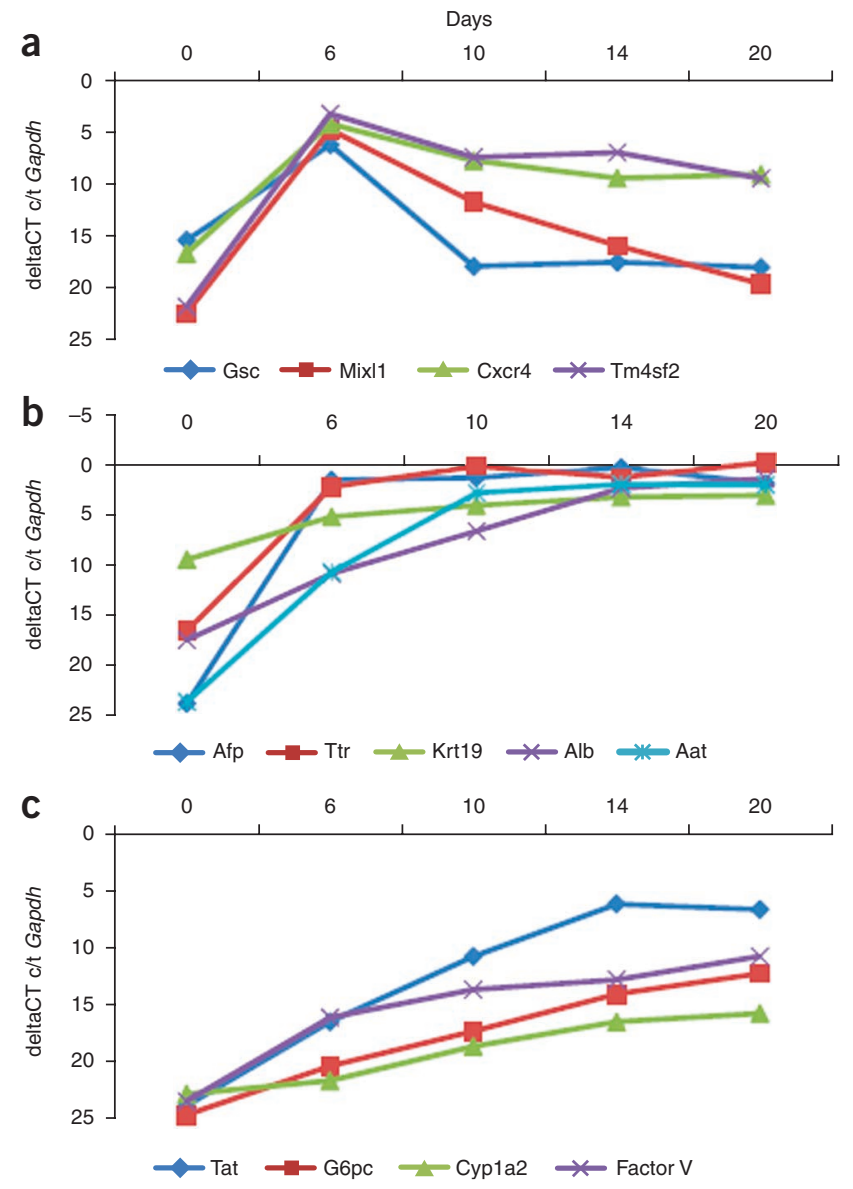
and $\mathbf{3}$, an extended list of assays that allow identification of hepatocyte-like cell differentiation is summarized.

\section{Gene expression profile of stem cell progeny}

Gene expression analysis can be performed on days 0,6 , 10,14 and 20 of differentiation to identify the correctly directed differentiation of the cells. Step 1 of the differentiation protocol clearly induces the expression of PS/ME/DE genes such us Gsc, Mixl1, Cxcr4 and Tm4sf2 (Fig. 3a). After stimulating first with BMP4 and FGF2 (Step 2), and then with FGF1, 4 and 8 (Step 3), those genes that are typically expressed in hepatoblasts and immature hepatocytes begin to be expressed (Afp, Ttr, Krt19, Alb, Aat) (Fig. 3 b). Step 4 induces the maturation of immature liver cells to a hepatocyte-like phenotype, which is revealed by the increased expression of genes expressed perinatally such as Tat, G6pc, Cyp450 and Factor V (Fig. 3c). Besides commitment to the liver, a fraction of cells is also directed to other endodermal (Pdx1, Cdx2, Tmprss2) and mesodermal cells (Sm22, $\alpha$-Sma, Cnn1, Nkx2.5, Tbx5).

Immunocytochemistry analysis shows that at day 0 nearly $100 \%$ of the cells are $0 \mathrm{ct} 4^{+}$Sox $7^{+}$Sox $17^{+}{ }^{+}$Foxa2 ${ }^{+}$

Figure 3 | RT-qPCR analysis of rMAPC progeny during liver differentiation, depicted as deltaCT compared with Gapdh (DeltaCT $\left.=\mathrm{CT}_{\text {gene }}-\mathrm{CT}_{\mathrm{GAPDH}}\right)$. The lower the DeltaCT value, the higher the expression level. (a) Induction of primitive streak/mesendoderm/definitive endoderm genes. (b) Induction of early liver-specific genes. (c) Induction of more mature liver-specific genes. 
Figure 4 | Immunocytochemistry analysis. (a) Undifferentiated rMAPCs are positive for 0ct4, Sox7, Sox17 and Foxa2 (scale bar, $100 \mu \mathrm{m})$. (b) Day 20 rMAPC progeny express albumin (green), $\alpha$-fetoprotein (red) and to a lesser extent Krt18 and Pepck (scale bar, $50 \mu \mathrm{m})$.

(Fig. 4a). At day 20, the differentiated stem cell progeny is a mixture of immature cells that coexpress Alb and Afp, and more mature cells expressing Alb but no longer Afp. Approximately $80 \%$ of differentiated cells expressed Afp, whereas expression of Alb was variable and patchy (range $5-30 \%$ $A\left(b^{+}\right)$. A small fraction of the progeny is $\mathrm{Krt} 18^{+}$and Pepck ${ }^{+}$(Fig. 4b). Electron microscopy studies of the differentiated population reveal cells with immature characteristics, together with cells with more mature hepatocyte characteristics (data not shown).

Hepatocytes exert a number of synthetic, storage and detoxifying functions. Thus, functional assays allow a more stringent characterization of stem cell progeny. As shown in a
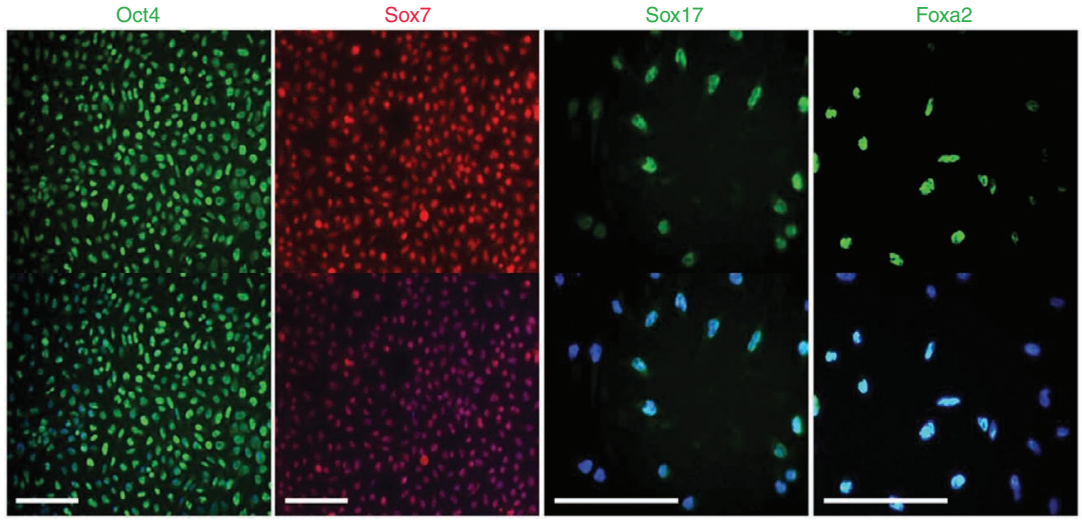

b
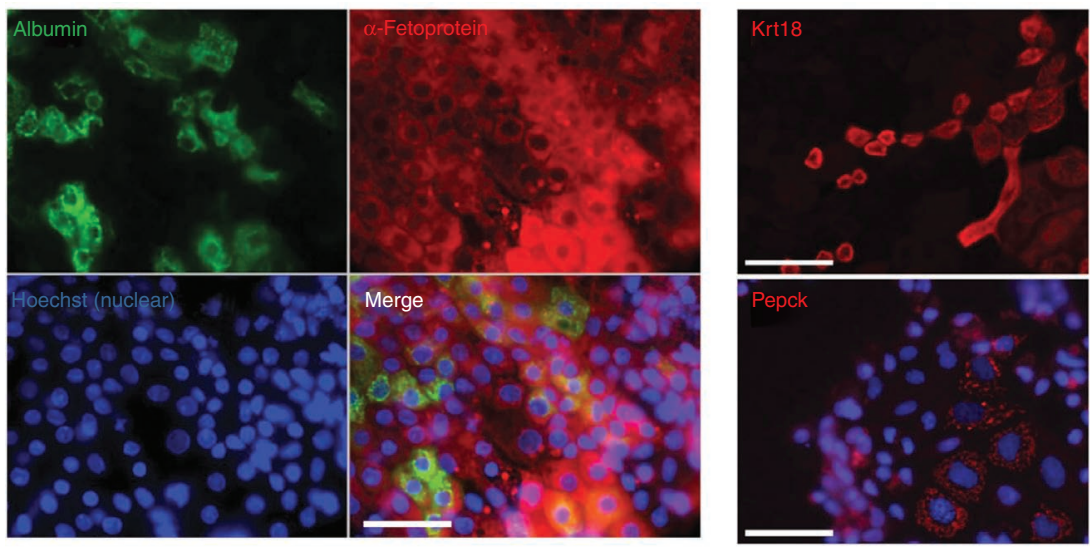

Figure $5 \mathbf{a}, \mathbf{b}$, differentiated cells produce albumin and store glycogen (in response to the glucose level in the medium). Moreover, stem cell progeny secrete urea, which is enhanced by the incubation with $\mathrm{NH}_{4} \mathrm{HCO}_{3}$ (Fig. 5c),
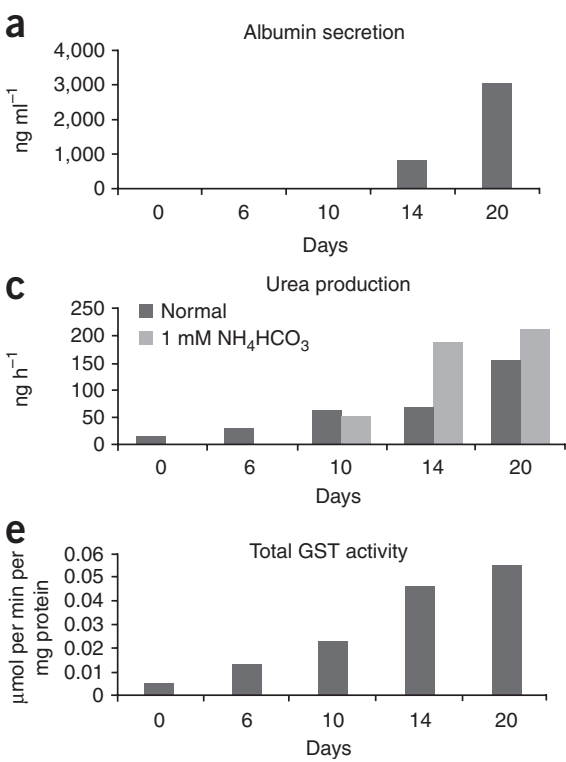

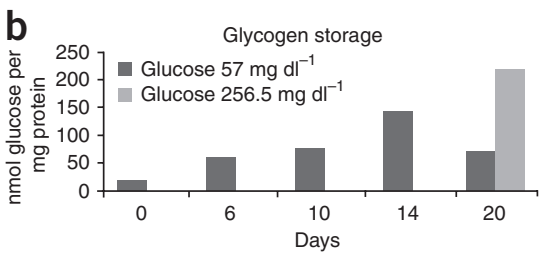

d

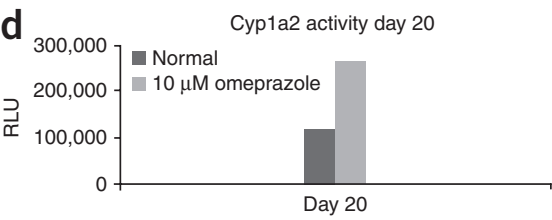

f

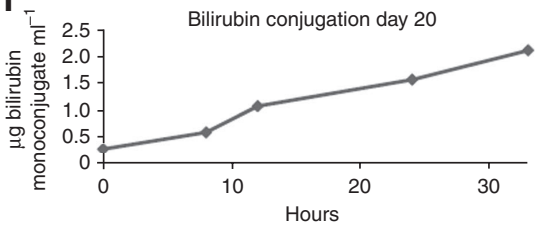

and have inducible cytochrome activity, as incubation of cells with omeprazole (as well as with phenobarbital, a well-known inducer of Cyp1a2) results in increased activity (Fig. 5d). Finally, hepatocyte-like cells are able to detoxify as demonstrated by GST activity (Fig. 5e) and bilirubin conjugation (Fig. 5f).

Figure 5 | Functional assays on rMAPC progeny (one representative experiment) during liver differentiation. (a) Albumin secretion; (b) glycogen storage in relation to low and high concentrations of glucose; (c) urea production in relation to ammonia; (d) rMAPC $\mathrm{d} 20$ progeny Cyp1a2 activity, inducible with omeprazole; (e) GST activity; and (f) rMAPC $d 20$ progeny bilirubin conjugation.
ACKNOWLEDGMENTS We thank F. Nevens, J. van Pelt, P. Windmolders, I. Vander Elst and M. Zeegers (Hepatology Lab, K.U. Leuven) for their help with functional assays and T. Notelaers (SCIL) for help with differentiation studies. This work was supported by grants to C.V. from the NIH (R01-HL67932, R01 DK58295, R01-HL073221 and U19-DK61244), the Alpha 1 Foundation, FW0 G.0667.07 Odysseus award and a K.U. Leuven SCIL Center of Excellence Award. C.V. also received research funding from Athersys Inc. (Cleveland, $\mathrm{OH}$, USA). P.R. was funded by IWT and VVGE. P.S.-B. was funded by FWO
(KAN 1.5163.09) and Agència de Gestió d'Ajuts Universitaris i de Recerca, Beatriu de Pinós (2006 BP-A 10104). K.P. was funded by FW0, BAEF and VVGE.

AUTHOR CONTRIBUTIONS P.R. and P.S.-B. prepared the manuscript. K.P. and C.V. designed the protocol. P.R., P.S.-B. and K.P. conducted the experiments, RT-qPCR, immunocytochemistry and functional assays. C.V. supervised the project. 
PROTOCOL

COMPETING FINANCIAL INTERESTS The authors declare no competing financial interests.

Published online at http://www.natureprotocols.com/.

Reprints and permissions information is available online at http://npg.nature.com/ reprintsandpermissions/.

1. Subramanian, K. et al. in Cellular Programming and Reprogramming: Methods and Protocols 1st edn. (ed. Ding, S.) 55-78 (Humana Press, 2010).

2. Breyer, A. et al. Multipotent adult progenitor cell isolation and culture procedures. Exp. Hematol. 34, 1596-1601 (2006).

3. Ulloa-Montoya, F. et al. Comparative transcriptome analysis of embryonic and adult stem cells with extended and limited differentiation capacity. Genome Biol. 8, R163 (2007).

4. Mitsui, K. et al. The homeoprotein Nanog is required for maintenance of pluripotency in mouse epiblast and ES cells. Cell 113, 631-642 (2003).

5. Kunath, $\mathrm{T}$. et al. Imprinted X-inactivation in extra-embryonic endoderm cell lines from mouse blastocysts. Development 132, 1649-1661 (2005).

6. Debeb, B.G. et al. Isolation of 0ct4-expressing extraembryonic endoderm precursor cell lines. PLOS ONE 4, e7216 (2009).

7. Jiang, Y. et al. Pluripotency of mesenchymal stem cells derived from adult marrow. Nature 418, 41-49 (2002).

8. Kogler, G. et al. A new human somatic stem cell from placental cord blood with intrinsic pluripotent differentiation potential. J. Exp. Med. 200, 123-135 (2004).

9. Yoon, Y.S. et al. Clonally expanded novel multipotent stem cells from human bone marrow regenerate myocardium after myocardial infarction. J. Clin. Invest. 115, 326-338 (2005).

10. D'Ippolito, G. et al. Marrow-isolated adult multilineage inducible (MIAMI) cells, a unique population of postnatal young and old human cells with extensive expansion and differentiation potential. J. Cell Sci. 117 2971-2981 (2004).

11. De Coppi, P. et al. Isolation of amniotic stem cell lines with potential for therapy. Nat. Biotech. 25, 100-106 (2007).

12. Dan, Y.Y. et al. Isolation of multipotent progenitor cells from human fetal liver capable of differentiating into liver and mesenchymal lineages. Proc. Natl. Acad. Sci. USA 103, 9912-9917 (2006).

13. Kucia, M. et al. A population of very small embryonic-like (VSEL) CXCR4+ SSEA-1+ 0ct-4+ stem cells identified in adult bone marrow. Leukemia 20, 857-869 (2006).
14. Anjos-Afonso, F. \& Bonnet, D. Non-hematopoietic/endothelial SSEA-1+ cells defines the most primitive progenitors in the adult murine bone marrow mesenchymal compartment. Blood 109, 1298-1306 (2007).

15. Beltrami, A.P. et al. Multipotent cells can be generated in vitro from several adult human organs (heart, liver, and bone marrow). Blood 110, 3438-3446 (2007).

16. Schwartz, R.E. et al. Multipotent adult progenitor cells from bone marrow differentiate into functional hepatocyte-like cells. J. Clin. Invest. 109, 1291-1302 (2002).

17. Lee, 0.K. et al. Isolation of multipotent mesenchymal stem cells from umbilical cord blood. Blood 103, 1669-1675 (2004).

18. Chien, C.C. et al. In vitro differentiation of human placenta-derived multipotent cells into hepatocyte-like cells. Stem Cells 24, 1759-1768 (2006).

19. Snykers, S. et al. Sequential exposure to cytokines reflecting embryogenesis: the key for in vitro differentiation of adult bone marrow stem cells into functional hepatocyte-like cells. Toxicol. Sci. 94, 330-341 (2006).

20. Snykers, S., De Kock, J., Rogiers, V. \& Vanhaecke, T. In vitro differentiation of embryonic and adult stem cells into hepatocytes: state of the art. Stem Cells 27, 577-605 (2009).

21. Banas, A. et al. Adipose tissue-derived mesenchymal stem cells as a source of human hepatocytes. Hepatology 46, 219-228 (2007).

22. Lee, K.D. et al. In vitro hepatic differentiation of human mesenchymal stem cells. Hepatology 40, 1275-1284 (2004).

23. Grünewald, J.0., Walker, J.C. \& Strope, E.R. Photooxidation of xanthobilirubic acid in aqueous solution: product and mechanism studies. Photochem. Photobiol. 24, 29-40 (1976).

24. Seifter, S., Dayton, S., Novic, B. \& Muntwyler, E. The estimation of glycogen with the anthrone reagent. Arch. Biochem. 25, 191-200 (1950).

25. Habig, W.H., Pabst, M.J. \& Jakoby, W.B. Glutathione S-transferases. The first enzymatic step in mercapturic acid formation. J. Biol. Chem. 249, 7130-7139 (1974).

26. Muraca, M. \& Blanckaert, N. Liquid-chromatographic assay and identification of mono- and diester conjugates of bilirubin in normal serum. Clin. Chem. 29, 1767-1771 (1983).

27. Bradford, M.M. A rapid and sensitive method for the quantitation of microgram quantities of protein utilizing the principle of protein-dye binding. Anal. Biochem. 72, 248-254 (1976).

28. Sancho-Bru, P. et al. Stem and progenitor cells for liver repopulation: can we standardise the process from bench to bedside? Gut 58, 594-603 (2009). 